\title{
SOKRATES, AISCHINÉS A SOKRATOVSKÝ DIALÓG
}

LÍVIA FLACHBARTOVÁ, Katedra bioetiky UNESCO, Filozofická fakulta Prešovskej univerzity v Prešove, Prešov, SR

FLACHBARTOVÁ, L.: Socrates, Aeschines and the Socratic Dialogue FILOZOFIA, 74, 2019, No. 1, pp. $52-63$

The paper follows from new collection of Socratic studies Socrates and the Socratic Dialogue (2018) edited by Alessandro Stavru a Christopher Moore. The author points to increased interest of scholars in re-examining Socratic philosophy, presents so-called "minor Socratics" as important figures of the Socratic movement, and reflects their significance for the study of Socrates philosophy and its legacy. Final part outlines philosophical relevance of Aeschines of Sphettus.

Keywords: Socrates - Socratic dialogue - Minor Socratics - Aeschines of Sphettus

V roku 2018 vydavatel'stvo Brill vydalo očakávanú publikáciu Socrates and the Socratic Dialogue, venovanú otcovi západnej filosofie ${ }^{1}$ Sokratovi. Zostavili ju Alessandro Stavru a Christopher Moore. Možno práve preto, že o Sokratovi nevieme takmer nič isté, možno práve preto, že každý pokus vyrovnat' sa so Sokratom či uchopit' jeho osobnost', život alebo filosofiu vyvoláva viac otázok ako odpovedí, alebo preto, že sa zachovala bohatá tradícia, ktorú Sokrates ovplyvnil a ktorá sa sformovala ako priama reakcia na jeho pôsobenie, a tým vykresala kontúry západného spôsobu filosofovania, neprestáva táto enigmatická postava s mnohými tvárami na seba pútat' pozornost' historikov, ktorí hl'adajú stále nové cesty ako sa jej približit'.

Ako uvádzajú zostavovatelia zborníka Christopher Moore a Alessandro Stavru v úvodnej štúdii, na poli sokratovských skúmaní sa revitalizovali základné témy a otázky, ktorým bádatelia $\mathrm{v}$ druhej polovici dvadsiateho storočia $\mathrm{z}$ vel'kej miery prestali venovat' pozornost', napr. „,sokratovská otázka“, teda problém, ktorý sa týka historického Sokrata, sokratovský krúžok, „malé sokratovské školy“, relevancia neskorších obrazov Sokrata a pod. Uplynulé desat'ročie prinieslo niekol'ko obsiahlych zborníkov $^{2}$ venovaných Sokratovi, pričom v nich môžeme nájst' štúdie zamerané na otázky spojené s Platónovým a Xenofónovým Sokratom, no v rámci ktorých dostávajú čoraz viac priestoru malí sokratovci, ako aj Sokratom ovplyvnené tradície, na čele ktorých títo sokratovci stoja. Zvýšený záujem historikov o prvú generáciu

\footnotetext{
${ }^{1}$ Neštandardné prepisovanie gréckeho slova filosofia s grafémou „s“ vysvetl'uje diskusia, ktorá prebehla v časopise Filozofia [2000, 55 (5) a (8); 2001, 56 (1) a (3)].

${ }^{2}$ Porov. Stavru, Moore (2018, 1, pozn. 1).
} 
sokratovcov, ako aj o sokratovské školy, dokladajú aj preklady, monografie, zborníky a množstvo štúdií, ktoré v posledných desat'ročiach vznikli. ${ }^{3}$

Zborník Socrates and the Socratic Dialogue je však výnimočný nielen čo sa týka rozsahu (má vyše 900 strán), ale aj svojím obsahom. Napriek tomu, že nedeklaruje snahu systematicky postihnút' tradíciu, ktorá sa bezprostredne týka Sokrata, kniha „ponúka komplexný obraz Sokrata a sokratovského dialógu v starovekej gréckej a rímskej literatúre od Eupolových a Aristofanových komédií napísaných počas Sokratovho stredného veku až po Proklove spisy, napísané viac ako osemsto rokov neskôr" (Moore, Stavru 2018, 3).

Zborník je rozdelený do piatich tematických okruhov a spolu s úvodnou štúdiou obsahuje štyridsatjeden štúdí. Stručne si načrtnime jednotlivé časti: (1) Prvý okruh štúdií načrtáva vplyv komédií piateho storočia pred Kristom na politickú a filosofickú motiváciu sokratovcov vyobrazit' svojho Majstra prostredníctvom nového literárneho žánru ( $\lambda$ ó jeho života zo strany sofistov a významných rečníkov. (2) Nasledujúca čast' je venovaná najbližším Sokratovým žiakom, známym ako „sokratovský krúžok“, ku ktorým zarad’ujeme najstarších Sokratových žiakov, napr. Aischina, Antisthena, Eukleida, Faidóna či Aristippa Staršieho. Ďalšie dva okruhy sú zamerané na „tradičných“ sokratovcov prvej generácie, ktorých sokratovské dialógy sa nám zachovali, teda na (3) Platóna a (4) Xenofóna. Napokon, záverečná čast' (5) sa orientuje na neskoršiu recepciu Sokrata $\mathrm{v}$ antike, Aristotelom počnúc a Proklom končiac. Už z tohto stručného zhrnutia obsahu je jasné, že táto publikácia je vskutku reprezentatívna a ponúka najnovšie výsledky bádania vo vzt’ahu k Sokratovi a sokratovskej tradícii z pera renomovaných odborníkov z celého sveta. Jedným z nich je aj Vladislav Suvák, ktorý do zborníka prispel štúdiou o Antisthenovi (On the Dialectical Character of Antisthenes' Speeches ,Ajax'and ,Odysseus', s. 141160). Štúdia zasadzuje Antisthenove epideiktické reči Aias a Odysseus, ktoré sa tradične pokladajú za práce $\mathrm{z}$ jeho obdobia, ovplyvneného gorgiovskou rétorikou $\left[\begin{array}{llll}S S R & \mathrm{~V} & \mathrm{~A} 11\end{array}\right]^{4}$, do kontextu sokratovskej dialektiky. To otvára priestor prehodnoteniu vzt’ahu medzi dialektikou a rétorikou, ktoré sú v sokratovskej tradícii, najmä pod vplyvom Platóna, často vnímané ako vylučujúce sa protiklady.

\footnotetext{
${ }^{3}$ Uved'me aspoň tie najdôležitejšie: Branccaci (1990); Vander Waerdt (ed.) (1994); Giannantoni \& et all. (1995); Branham - Goulet-Cazé (eds.) (1996); Rossetti - Stavru (eds.) (2008) a (2010); Boys-Stones - Rowe (eds. \& tran.) (2013); Luise - Stavru (eds.) (2013); Suvák (ed.) (2014a), Prince (2015); Zilioli (2014); Zilioli (ed.) (2015) atd’. Stav sokratovských štúdií do roku 2013 podrobne mapuje A. Stavru $(2013,11-26)$.

${ }^{4}$ Porov. prislúchajúci komentár V. Suváka (Kalaš, Suvák 2013, 44 - 46); pozri aj úvodný komentár k obidvom rečiam (Kalaš, Suvák 2013, 141 - 153).
} 
V rámci tejto recenznej štúdie sa nebudeme podrobne zaoberat' jednotlivými príspevkami, ale zameriame sa na okruh prvej generácie sokratovcov, a na posun v sokratovských skúmaniach, ktorý jej štúdium prináša. V záverečnej časti sa upriamime na Aischina zo Sféttu a načrtneme jeho podobu sokratiky na pozadí štúdie Claudie Mársico, ktorá je súčast'ou zborníka Socrates and the Socratic Dialogue.

Sokrates a malí sokratovci. Dominantná interpretačná línia sa opiera najmä o Platónovho Sokrata, resp. o Sokrata raných Platónových dialógov, teda o vymedzenie do väčšej či menšej miery zodpovedajúce Vlastosovej charakteristike (Vlastos 1991, 45 - 80). No v uplynulých desat'ročiach sa začala rozvíjat' línia, ktorá vo vzt’ahu $\mathrm{k}$ Sokratovi vychádza nielen $\mathrm{z}$ tradičnej štvorice prameňov, ktorá pozostáva z Aristofana, Xenofóna, Platóna a Aristotela, ale zdôrazňuje dobové intelektuálne prostredie a skutočnost', že sokratovské rozpravy písali Sokratovi žiaci často ako reakciu - v mnohých prípadoch na seba navzájom. Tento postoj umožňuje pristúpit' $\mathrm{k}$ takzvaným malým sokratovcom ${ }^{5}$ ako $\mathrm{k}$ relevantnému zdroju informácií o Sokratovi a jeho spôsobe života a myslenia - a to aj napriek fragmentárnej podobe zachovaných diel (v mnohých prípadoch sa zachovali iba tituly) a často protirečivým svedectvám s nejasnou historickou hodnotou o ich živote a učení. V tomto svetle zároveň možno korigovat' a reinterpretovat' paradigmatické postavenie Platóna vo vzt’ahu k skúmaniu Sokratovej filosofie, čo otvára cestu k pochopeniu sokratiky, ktorá sa primárne neodvíja od dedičstva Platónovho Sokrata, ale vzniká ako mozaika rôznych podôb sokratovských problematizácií dobrého života. V tomto zmysle dôležité miesto nadobúdajú aj dobové polemiky so Sokratom zo strany nesokratovcov, najmä sofistov a autorov komédií a textov, ktoré spoluutvárali myšlienkové, literárne a rétorické pozadie Sokratovho pôsobenia.

Staroveké pramene a doxografie sú plné zmienok o Sokratových žiakoch, no napriek tomu o nich vieme iba vel'mi málo. Iste, súvisí to v prvom rade s tým, že ich diela sa nezachovali, resp. že sa $\mathrm{z}$ nich zachovali iba fragmenty či parafrázy v dielach iných autorov. Avšak ich marginalizácia v modernej historiografii a dejinách filosofie súvisí aj s tým, ako historici filosofie pristupovali k chápaniu nielen antickej filosofie, ale aj s tým, čo očakávali od filosofie vôbec. Požiadavka, ktorá vystupovala do popredia, sa týkala systematickosti a univerzálnosti: produktom filosofie má byt' univerzálny systém, ktorý zahŕňa celú skutočnost'. Ak čítame dejiny filosofie cez optiku takejto požiadavky, l'ahko môžeme nájst' líniu myslitel'ov, ktorí jej vyhovejú - od Platóna až po Hegela, posledného myslitel’a vel'kého systému.

\footnotetext{
${ }^{5} \mathrm{~V}$ antike sa stretneme s označením oí $\Sigma \omega \kappa \rho \alpha \tau$ «oí (Diog. Laert. II. 47), ktorý odkazuje na sokratovcov prvej generácie. Prívlastok „malí“ sa vo vzt’ahu k sokratovcom používa v moderných prácach pod vplyvom E. Zellera (1922; 1. vyd. 1859), pričom implicitne vyjadruje nižšiu mieru originálnosti a filosofickej erudície týchto sokratovcov v porovnaní s Platónom. V súčasnosti sa na označenie prvej generácie Sokratových nasledovníkov čoraz častejšie používa výraz „sokratovci“ bez prívlastku „malî“. Tento výraz sa zároveň použiva aj širšie - a to na označenie tých po grécky a po latinsky píšucich autorov, ktorí sa hlásili k Sokratovi.
} 
A samozrejme, že z tohto pohl'adu sa nesystematickí filosofi môžu zdat' nezaujímaví, ba dokonca až banálni. ${ }^{6}$

Výborným príkladom takéhoto prístupu je Eduard Zeller, ktorý vo svojej vplyvnej „učebnici“ dejín gréckej filosofie (Zeller 1922, 39 - 40) označuje sokratovcov (vynímajúc Platóna) ako „die unwollkommenen Sokratikern“, teda „nedokonalých“, „neúplných“ sokratovcov a vykresl’uje kontinuálnu historickú líniu Sokrates - Platón - Aristoteles, ktorú narúšajú „nedokonalé pokusy rozšírit’ sokratovský princíp“ megarskou, kynickou a kyrenaickou školou. Dodáva, že vzhl'adom na to, že filosofiu obmedzili na subjektívne cvičenie myslenia a charakteru, nedochádza $\mathrm{v}$ rámci týchto škôl $\mathrm{k}$ žiadnemu posunu filosofického uvedomenia, ked’že filosofia už v čase Sokrata dospela k princípu objektívneho poznania, ktoré možno budovat' jedine v systéme. Napriek tomu Zeller uznáva, že malí sokratovci neboli celkom nedôležití - na jednej strane ich považuje za východisko stoicizmu, epikureizmu a skepticizmu, na druhej strane pripúšt’a, že ich skúmania mali vplyv aj na Platóna a Aristotela. To však nič nemení na tom, že podla Zellera sa väčšina Sokratových nasledovníkov obmedzovala na to, čo bolo bezprostredne zrejmé a malo blízko $\mathrm{k}$ všeobecnej inteligencii, napríklad na originálnu osobnost', čistotu charakteru, rozumný pohl'ad na život, hlbokú zbožnost' či krásu morálnych maxím svojho učitel'a (Zeller 1922, 197), pričom k nim radí aj Xenofóna, ktorý podl'a neho nepochopil skutočnú filosofickú hodnotu diskusií, o ktorých písal (Zeller 1922, 200).

Keby sme však zmenili naše vstupné očakávania a pokúsili sa vo filosofii hl'adat' niečo viac ako len teoretickú argumentáciu slúžiacu na poznanie skutočnosti a života človeka v nej, keby sme si pripomenuli jeden zo základných princípov antickej filosofie, totiž že život filosofa je miestom skúšky jeho učenia, a teda ich od seba nemožno oddelit', vynorila by sa potreba citlivejšej pozornosti $\mathrm{k}$ dobovému kontextu, k životu, ktorý filosof viedol, k l’ud'om, s ktorými sa stýkal a pod. ${ }^{7}$ Inými slovami, ak pristúpime $\mathrm{k}$ filosofii ako k spôsobu života, ukáže sa, že filosofický diskurz nie je to, k čomu filosofická aktivita primárne smeruje, ale že je výrazom

\footnotetext{
${ }^{6}$ Tento osud do určitej miery postihol aj Xenofóna, ktorý bol dlhodobo, až do 18. stor., pokladaný za najvernejší zdroj, vedúci k historickému Sokratovi. Pod vplyvom Schleiermachových prác sa historici začali prikláňat' na stranu Platóna. Podrobne o tejto otázke píše Dorion (2011). Porov. Hegel $(1965,79-80)$ : Hegel hovorí o sokratovcoch ako o tých, ktorí Sokrata v ničom neprekročili a iba jednostranne rozvinuli jeho princíp výchovy, pričom ako najslávnejšieho z nich uvádza Xenofóna.

${ }^{7}$ To platí aj pre čítanie Platóna a interpretáciu Platónovho Sokrata: Ak sa prestaneme zameriavat' iba na analýzu jednotlivých problémov, rekonštrukciu argumentov a ich vzájomné pomeriavanie a porovnávanie, ak si pri čítaní jeho dialógov budeme všímat' aj celkový kontext dialógu a jeho dramatickú výstavbu, objaví sa pred nami Sokrates, ktorý nielenže neúnavne diskutuje a skúma všetky názory a mienky, ktoré sa týkajú zdatnosti a dobrého života, ale navyše má „schopnost' liečit', t. j. pomáhat' pomocou rozhovorov sebe a svojim blízkym starat' sa o seba" (Suvák, 2016a, 9). Sokratovskou therapeiou a terapeutickým čítaním Platónových dialógov sa podrobne zaoberá V. Suvák (2014b; 2016a; 2016b; 2018b).
} 
hl'adania a súčast’ou úsilia o dobrý život, ktorý je vždy individuálnym životom sprevádzaným individuálnym hl’adaním a konkrétnymi praktikami vykonávanými na sebe za účelom jeho zlepšenia. ${ }^{8}$

Sokrates, ktorého poznáme, teda Platónov a Xenofónov Sokrates, je najmä literárnou postavou, preto otázka možností poznania historického Sokrata po stáročia trápila historikov, ktorí napokon dospeli $\mathrm{k}$ záveru, že jediné, čo o historickom Sokratovi s istotou vieme - okrem toho, že žil a mal svojich nasledovníkov -, je rok jeho smrti a znenie obžaloby. O Sokratovej filosofii hovoríme vždy sprostredkovane, cez sokratovcov - nielen jeho priamych žiakov, ale aj ich nasledovníkov - a bohatej tradície hlásiacej sa k Sokratovmu odkazu. Práve preto je nielen zaujímavé, ale aj dôležité skúmat takpovediac celý sokratovský kontext: nielen rôzne podoby Sokrata ako literárnej postavy, ale aj rôzne podoby vplyvu, ktorý mal na svojich žiakov a nasledujúce generácie. V tomto duchu píšu aj zostavovatelia zborníka úvodné slová: „Spôsob, akým Sokrates žil svoj život - na verejnosti, v ustavičných rozhovoroch, v snahe získat' sl'ubných mladíkov obce filosofiou spoločného skúmania - znamená, že skúmat' Sokrata vyžaduje skúmanie jeho účinku a vplyvu na tých okolo neho, a následne na tých okolo nich" (Stavru, Moore 2018, 4).

Ak sa sústredíme na otázku sokratovského dialógu, zistíme, že sme v podobnej situácii ako so Sokratom. Paradigmatickým autorom sokratovských dialógov je pre mnohých historikov Platón. Napriek tomu, že jeho spisovatel'skú genialitu nemožno popriet', $v$ rámci skúmania sokratiky sa vynára otázka v súvislosti s miestom a úlohou sokratovských dialógov z pera d'alších sokratovcov. Podobne ako sa líši vyobrazenie Sokrata u každého z nich, líši sa aj forma a podoba ich sokratovských dialógov. ${ }^{9}$ Platónove dialógy môžeme porovnávat' v prvom rade s Xenofónovými, ktoré sa zachovali kompletné. Avšak zachované fragmenty z dialógov malých sokratovcov nám dovol'ujú aspoň čiastočne rekonštruovat' ich obsah aj formálnu stránku, na základe čoho si vieme urobit' predstavu o ich rozvinutí Sokratovho odkazu ako o jednej z podôb sokratiky, a nielen načrtnút' d’alšie obrazy Sokrata, ale aj prehodnotit’ ten dominantný, teda platónsko-xenofónovský. Navyše nie v každom sokratovskom dialógu vystupuje Sokrates ako hlavná postava, respektíve klúčcov́ diskutér, čo možno pokladat' za d’alší rozmer sokratovskej literatúry, ktorý štúdium

\footnotetext{
${ }^{8}$ Prelomové práce vo vzt'ahu k chápaniu filosofie ako spôsobu života napísal francúzsky historik Pierre Hadot. Pozri Hadot (1995) a (2017).

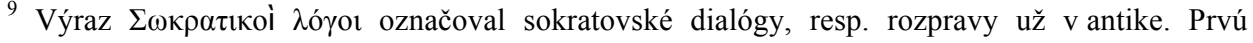
zmienku nachádzame v Aristotelovej Poetike (Arist. Poet. II. 1447b11), ktorý charakterizuje

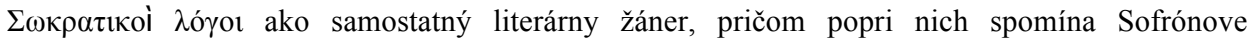
a Xenarchove mímy. Otázkou mimetického charakteru sokratovských dialógov sa podrobne zaoberá Ford $(2010,221$ - 235), ktorý ukazuje, že dôvod Aristotelovho zaradenia tohto žánru medzi mimetické, nesúvisel s literárnou dramatizáciou filosofických rozhovorov, ale najmä s tým, že v rámci neho sa rozvíjal logos bez hudby alebo metra na vyobrazenie etických volieb. Pozri aj Clay (1994). Prehodnotením povahy sokratovských dialógov a vzt'ahov medzi ich autormi s prihliadnutím na Platóna a Xenofóna sa zaoberá Redfield (2018).
} 
sokratovcov obohacuje.

Malí sokratovci začnú byt' filosoficky významní, až ked’ si uvedomíme dôležitost' uvedenej zmeny uhla pohl'adu, začneme prihliadat' aj na celkový kontext pomerov medzi sokratovcami a rôzne podoby sokratovskej literatúry, a pochopíme ich filosofiu ako úsilie viest' svoj život určitým spôsobom, ako výraz starosti o seba. ${ }^{10}$ Vo vzt'ahu k Sokratovi a bezprostrednej antickej tradícii, ktorá sa k nemu hlásila, urobil nedocenitel'nú prácu Gabriele Giannantoni. Vo svojom monumentálnom diele Socratis et Socraticorum Reliquiae (1990) zozbieral a usporiadal všetky pasáže, $v$ ktorých sa nachádzajú parafrázy a citáty z diel, ale aj zmienky a príbehy zo životov sokratovcov prvej generácie a ich nasledovníkov. Túto edíciu zozbieraných prameňov $\mathrm{v}$ gréčtine a latinčine možno právom pokladat' za jeden $\mathrm{z}$ hlavných pilierov obnoveného záujmu nielen o malých sokratovcov, ale aj o tradičné, a zároveň opustené sokratovské otázky. ${ }^{11}$ Napriek tomu Giannantoniho edícia stále nebola kompletne preložená do žiadneho jazyka. V súčasnosti existujú preklady výberov zlomkov $\mathrm{k}$ jednotlivým sokratovcom $^{12}$ a iba $\mathrm{v}$ ojedinelých prípadoch máme $\mathrm{k}$ dispozícii preklad všetkých zlomkov niektorého zo sokratovcov. ${ }^{13} \mathrm{O}$ to potešujúcejšia je skutočnost', že slovenskí bádatelia venujú svoje úsilie príprave edície Fontes Socraticorum, v rámci ktorej vyšli už prvé dva zväzky s kompletným prekladom Antisthenových (Antisthenis fragmenta) a Diogenových zlomkov (Diogenis fragmenta) s podrobným komentárom. ${ }^{14}$ Pripravovaný tretí zväzok sa bude týkat' práve Aischina.

Aischinés zo Sféttu. Aischinés patril k najstarším a najbližším Sokratovým žiakom ([SSR VI A 3], [SSR VI A 6], [SSR VI A 30] atd'.). Je spomenutý v Platónovej Obrane (Plat. Apol. 33e) medzi tými, ktorí boli prítomní na súde so Sokratom, a vo Faidónovi (Plat. Phd. 59b) vo výpočte tých, ktorí so Sokratom prežili vo väzení jeho posledné chvíle. U Xenofóna, naopak, nenájdeme ani jednu zmienku o Aischinovi (pričom sa v jeho sokratovských dialógoch môžeme stretnút' napríklad s Antisthenom či Aristippom). Diogenes Laertský zarad’uje Aischina k najznámejším sokratovcom (Diog. Laert. II.47), avšak jeho biografický portrét (Diog. Laert. II.60 - 64) je pomerne krátky a povaha správ v ňom obsiahnutá je

\footnotetext{
10 Porov. Hadot $(2017,15)$, „... žádná filosofie ani žádný filosof nestojí osamoceně mimo komunitu, mimo pospolitost, jinak řečeno mimo filosofickou „školu“, a filosofická škola znamená přede-vším právě tuto volbu určitého způsobu života, existenciálni rozhodnutí, které požaduje od jednotlivce zásadní životní změnu, bytostnou transformaci, a v posledku je vyjádřením touhy žít a pobývat ve svété určitým způsobem.“

${ }^{11}$ Giannantoniho edícia vyniká svojou komplexnost'ou: prvé dva zväzky zahíňajú zozbierané svedectvá v gréčtine, ktoré sa viažu k Sokratovi, jeho najbližším žiakom a ich nasledovníkom; tretí zväzok pozostáva $\mathrm{z}$ rozsiahleho zoznamu literatúry a indexov k prvým dvom zväzkom a štvrtý obsahuje takmer 600-stranový komentár v taliančine.

${ }^{12}$ Napr. Boys-Stone, Rowe (2013).

${ }^{13}$ Napr. Prince (2015).

${ }^{14}$ Pozri Kalaš, Suvák (2013) a Cepko, Kalaš, Suvák (2016).
} 
značne ambivalentná. ${ }^{15}$ Protirečivé správy však nenachádzame iba u Diogena Laertského, ale platí to všeobecne pre povahu doxografickej tradície, ktorá sa týka Aischina. Jeden z najkontroverznejších bodov sa vzt'ahuje k Aischinovej literárnej činnosti. Na jednej strane máme správy o pochybovačoch a ohováračoch, ktorí Aischina nepokladajú za autora dialógov, ktoré sa mu pripisujú, ${ }^{16}$ dokonca ho obviňujú z plagiátorstva a krádeže. ${ }^{17} \mathrm{Na}$ druhej strane sa stretávame so silnou tradíciou antických autorov, ktorí vychval'ujú a vysoko oceňujú Aischinov literárny štýl, ${ }^{18}$ obhajujú ho ako vplyvného sokratovca ${ }^{19}$ a okrem iného naznačujú, že Aischinovo vyobrazenie Sokrata bolo najvernejšie spomedzi všetkých sokratovcov. $^{20}$

${ }^{15} \mathrm{~K}$ tomuto problému pozri štúdiu V. Suváka v tomto čísle, ktorý interpretuje dvojznačnú povahu doxografických správ o Aischinovi pomocou sokratovskej erotickej výchovy zobrazenej v Aischinovom dialógu Alkibiadés.

${ }^{16}$ Diogenes Laertský pripisuje Aischinovi sedem sokratovských dialógov: Miltiadés, Kallias, Axiochos, Aspasia, Alkibiadés, Télauges a Rinón. Okrem nich bol Aischinés údajne autorom aj tzv.

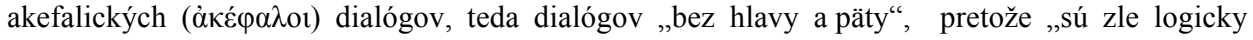
vystavané a nevyjadrujú sokratovského ducha“ (Diog. Laert. II.60; Suid. s. v. Aischinés). Navyše niektoré správy pripisujú Aischinovi aj autorstvo Simónových „obuvníckych dialógov“. Porov. [SSR VI A 23] a [SSR VI A 25].

${ }^{17}$ O pravosti Aischinových dialógov sa v antike hojne diskutovalo. Diogenes Laertský označuje za hlavného ohovárača Menedéma z Eretrie, ktorý tvrdil, že Aischinés vydával za svoje Sokratove dialógy, ktoré dostal po jeho smrti od jeho manželky Xantippy (Diog. Laert. II.60), čo je v rozpore s ustáleným názorom, že Sokrates nič nenapísal. Takisto Aristippos vraj spochybňoval Aischinovo autorstvo, ked' podl'a jednej anekdoty posmešne reagoval na Aischinovo verejné čítanie z jedného z dialógov: „Odkial' si to, ty zlodej, ukradol?“ (Diog. Laert. II.62). Na základe zachovaných správ môžeme usudzovat', že vzt’ah Aischina a Aristippa bol pomerne komplikovaný. Porov. [SSR VI A 4] a [SSR VI A 13].

${ }^{18}$ Hermog. De ideis II 12,2 [=SSR VI A 20] : „O sokratikovi Aischinovi. Aj on sám sa vyznačuje prostým štýlom v miere, akú t’ažko nájdeme u iného autora. Ešte viac ako jednoduchost'ou však vyniká čistotou a zrozumitel'nost'ou. V tomto ohl'ade je v slovných formuláciách ešte presnejší ako Xenofón. V porovnaní s ním totiž nepoužíva menej vznešených myšlienok, ale telesné rozkoše a súvisiace scény z mytológie zobrazuje ovel'a menej. O kol'ko vyniká jednoduchost'ou Xenofón nad Platónom, o tol'ko zas podl'a môjho skromného odhadu vyniká Aischinés presnost'ou vyjadrovania nad Xenofónom. Preto je od neho aj ovel’a zrozumitel'nejší a pri všetkej tej jednoduchosti aj vel'mi dôkladný - dokonca vo väčšej miere ako Xenofón.“ Preložil A. Kalaš. Porov. [SSR VI A 35].

${ }^{19}$ K nim môžeme zahrnút' aj Diogena Laertského, čo naznačuje už sama narážka na ohováranie v súvislosti s Menedemom. K otázke Diogenovho postoja k Aischinovým sokratovským dialógom pozri Beall (2001).

${ }^{20}$ Grécky rečník a predstavitel’ hnutia druhej sofistiky v 2. stor. po Kr. Ailios Aristeidés píše: „,... Aischina, Sokratovho žiaka, budeme považovat' za pravého filosofa. Na druhej strane stojí svedectvo niektorých l'udí, ktorí si nesprávne myslia, že spisy, o ktorých je reč [scil. Aischinove], napísal sám Sokrates. Ak ich názor nemáme celkom zavrhnút - ja osobne by som to určite nerobil - prídeme k záveru, že tento blud vznikol na základe nejakého reálneho podkladu. Spisy, o ktorých tu hovoríme, totiž pripadali všetkým také blízke a vlastné Sokratovej povahe, že l’ahko vznikol priestor pre takúto domnienku." (Ael. Aristid. De rhet. I 76 - 78 [=SSR VI A 30]). Preložil A. Kalaš. Porov. K. Döring (1984). 
Napriek tejto pomerne bohatej tradícii mu však historici doteraz venovali iba minimálnu pozornost', ${ }^{21}$ a to aj v porovnaní s d’alšími „,malými““ sokratovcami. Aischinés je zvláštna postava. Ako píše Claudia Mársico, je tým, ktorý je málo významný v skupine tých menej významných sokratovcov (Socratici minori). Toto postavenie však nemusí zodpovedat' jeho (skutočnej) pozícii v rámci sokratovského krúžku a treba si uvedomit', že je do vel'kej miery výsledkom interpretačných tendencií naprieč dejinami. Napriek tomu, že nezaložil školu, ani nemal žiadnych priamych nasledovatel'ov, patril k popredným sokratovcom prvej generácie. Štúdia Claudie Mársico s názvom Shock, Erotics, Plagiarism, and Fraud: Aspects of Aeschines of Sphettus' Philosophy, uverejnená v zborníku Socrates and the Socratic Dialogue, je skvelým príkladom práce s korpusom aischinovských fragmentov na ceste k oživeniu Aischina ako sokratovca, ktorý nielenže nadviazal na Sokratovu filosofiu, ale ju aj originálnym spôsobom rozvinul. Podl’a Mársico Aischinés vyvinul metódu „duševného šoku“ sprostredkovaného sokratovskou láskou (eros) s ciel'om vyvolat' potrebu zlepšit' samého seba. Túto metódu ilustruje prostredníctvom analýz a interpretácie zlomkov Aischinových dialógov Alkibiadés a Aspasia, v rámci ktorých hnacím motorom skúmania nie je elenchos s ciel'om priblížit' sa k vedeniu, ale opačný postup založený na Sokratovom pozmeňovaní zmýšlania a nálady jeho priatel'ov prostredníctvom pôsobenia lásky (eros) ako protreptického nástroja výchovy.

Sokratovská literatúra vykresl'uje Sokrata ako milovníka par excellence. Sokrates sa vždy zaujímal o nádejných mladíkov aténskej obce a viedol s nimi rozhovory na rôzne témy, čo napokon viedlo aj $\mathrm{k}$ jeho obžalobe a následnému odsúdeniu. ${ }^{22}$ Avšak Sokratovi spoločníci neboli výlučne mladíci a a nemožno všetkých z nich pokladat' za Sokratových miláčikov (eromenoi). ${ }^{23}$ Je teda namieste

\footnotetext{
${ }^{21}$ Pioniersku prácu venovanú Aischinovi, Aischines von Sphettus, vydal v roku 1912 nemecký historik Heinrich Dittmar, ktorý nielenže zozbieral fragmenty, ale taktiež podrobne zmapoval kl'účové témy a postavy Aischinových dialógov v kontexte ich výskytu a podôb u d'alších sokratovcov. Dittmarova práca bola jedinou monografickou prácou venovanou Aischinovi až do roku 1966, ked' vyšla monografia nemeckej historičky Barbary Ehlers, Eine vorplatonische Deutung des sokratischen Eros. Der Dialog Aspasia des Sokratikers Aischines. Ďalšia vel'ká práca o Aischinovi vyšla až po vyše pät’desiatich rokoch od publikovania práce B. Ehlers: V roku 2017 vydala talianska historička Francesca Pentassuglio kompletný preklad Aischinových zlomkov do taliančiny s podrobným komentárom (Eschine di Sfetto. Tutte le testimonianze). Kurt Lampe $(2015,61)$ si myslí, že jedným z dôvodov minimálneho záujmu o Aischina je presvedčenie, že je filosoficky málo zaujímavý a nemá čo ponúknut', ked’že dochované fragmenty neobsahujú žiadne špecifické argumenty k otázkam etiky, metafyziky či epistemológie. Lampe vo svojej štúdii načrtáva, ako zmena interpretačného rámca môže viest' k prekonaniu tohto predsudku. Namiesto analytického čítania volí foucaultovskú perspektívu, ktorá otvára možnosti prehodnotenia filosofického významu Aischina ako sokratovca. Prehl'ad vydaní Aischinových zlomkov od začiatku 18. stor. zostavila F. Pentassuglio $(2017,589-590)$. Základné práce k Aischinovi sú uvedené v zozname literatúry na konci tohto príspevku. Pozri aj Lampe $(2015,80-81)$.

${ }^{22}$ Porov. znenie Sokratovej obžaloby a bodu, ktorý sa týka kazenia mládeže: Plat. Apol. 24b - c; Diog. Laert. II. 40. Pozri aj Xenoph. Apol. $10-11$.

${ }^{23} \mathrm{~K}$ otázke pederastie ako výchovnej inštitúcie v starovekom Grécku pozri Dover (1978). K rôz-
} 
položit' si otázku, aký bol Sokratov vzt’ah k týmto jeho dospelým spoločníkom a nasledovatel'om, a aký prospech mali títo sokratovci zo Sokratovej spoločnosti? Podl'a Claudie Mársico je klúčom $\mathrm{k}$ tejto otázke Aischinovo vyobrazenie úlohy sokratovskej lásky (eros): fragmenty z jeho dialógu Alkibiadés môžu pomôct' osvetlit' vzt'ah Sokrata k jeho milovaným a fragmenty z Aspasie zas dovol'ujú rekonštruovat' to, akým spôsobom Sokrates prospieval svojim spoločníkom i ostatným l'ud'om a aký úžitok im Sokratov eros prinášal (Mársico 2018, 203).

V oboch prípadoch máme nastolenú situáciu, ktorá pôsobí bezvýchodiskovo: Alkibiadés je arogantný a pyšný a zdá sa, že jeho charakter už nemôže nič napravit' - a oproti nemu stojí Themistoklova prevaha nad všetkými ostatnými politikmi ([SSR VI A 42], [SSR VI A 46], [SSR VI A 47]); Xenofón a jeho manželka sa často hádajú, čo navodzuje dojem, že ich vzt'ah už nemožno zachránit' [SSR VI A 70] a Aspasia ich postaví pred možnost' výberu iných (lepších) partnerov. Sokrates (respektíve Aspasia v Sokratovom rozprávaní) otrasie pôvodným duševným naladením aktérov dialógu pomocou vyhrotených a provokatívnych príkladov. Napokon v oboch prípadoch zohrá klúčcvú úlohu eros - láska medzi Sokratom a Alkibiadom, a Xenofónom a jeho manželkou, ktorá vedie $\mathrm{k}$ uvedomeniu potreby starosti o seba, práce na sebe za účelom zlepšenia seba samého, je riešením otraseného vedomia, duševného stavu navodeného Sokratom, resp. Aspasiou (Mársico 2018, 209). ${ }^{24}$

Na záver môžeme skonštatovat', že práca historikov na poli sokratovských štúdií v posledných desat'ročiach bezprecedentne napreduje (pričom nezaostávajú ani slovenskí autori) a otvára množstvo nových otázok a možností skúmania - nielen v súvislosti s vypíňaním „bielych miest“" na mape antickej filosofie, ale aj vo vzt’ahu $\mathrm{k}$ reinterpretácii sokratovskej tradície.

\section{Literatúra}

BEALL, E. F. (2001): Diogenes Laertius on Aeschines the Socratic's Works. Hermes 129 (1), 142 $-144$.

BOYS-STONES, G. - ROWE, Ch. (eds. \& tran.) (2013): The Circle of Socrates. Readings in the First-Generation Socratics. Hackett Publishing Company.

BRANCACCI, A. (1990): Oikeios Logos: La filosofia del linguaggio di Antistene. Elenchos 20. Napoli, Bibliopolis.

BRANHAM, R. B. - GOULET-CAZÉ, M.-O. (eds.) (1996): The Cynics: The Cynic Movement from Antiquity and Its Legacy. Berkeley and Los Angeles: University of California Press.

CEPKO, J., KALAŠ, A., SUVÁK, V. (2016): Diogenis fragmenta / Diogenove zlomky. Úvodná štúdia, preklad zlomkov a komentár. Fontes Socraticorum II. Bratislava: Univerzita Komenského v Bratislave.

nym podobám Sokrata ako milovníka-vychovávatel’a pozri Johnson - Tarrant (2012).

${ }^{24}$ Bližšie pozri podrobný výklad erotickej výchovy Aischinovho Sokrata v tomto čísle (J. Cepko; A. Kalaš, Z. Zelinová). 
CLAY, D. (1994): The Origins of the Socratic Dialogue. In: Vander Waerdt, P. A. (ed.): The Socratic Movement. Ithaca: Cornell University Press, 23 - 47.

DITTMAR, H. (1912): Aischines von Sphettos. Studien zur Literaturgeschichte der Sokratiker. Berlin: Weidmannsche Buchhandlung.

DORION, L.-A. (2011): The Rise and Fall of the Socratic Problem. In: D. R. Morrison (ed.): The Cambridge Companion to Socrates. New York: Cambridge University Press, 1 - 23.

DOVER, K. J. (1978): Greek Homosexuality. London: Duckworth \& Co.

DÖRING, K. (1984): Der Sokrates des Aischines von Sphettos und die Frage nach dem historischen Sokrates. Hermes, 112 (1), 16 - 30.

EHLERS, B. (1966): Eine vorplatonische Deutung des sokratischen Eros. Der Dialog Aspasia des Sokratikers Aischines. Zetemata 41. München: Verlag C. H. Beck.

FORD, A. L. (2010): $\Sigma \Omega$ KРАТІКОI $\Lambda$ ОГОI in Aristotle and Fourth-Century Theories of Genre. Classical Philology, 105 (3), 221 - 235.

GIANNANTONI, G. (1991): Socratis et Socraticorum Reliquiae. 4 Vol. Elenchos 18. Napoli: Bibliopolis (skratka $S S R$ ).

GIANNANTONI, G. \& et all. (1995): La tradizione socratica. Napoli: Bibliopolis.

GRIBBLE, D. (1999): Plato and the Socratics. In: D. Gribble (ed.): Alcibiades and Athens: A Study in Literary Presentation. Oxford: Oxford University Press, 214 - 259.

HADOT, P. (1995): Philosophy as a Way of Life. Spiritual Excercises from Socrates to Foucault. Prel. M. Chase. Oxford, New York: Blackwell.

HADOT, P. (2017): Co je antická filosofie? Prel. M. Kř́žová. Praha: Vyšehrad.

HEGEL, G. W. F. (1965): Dějiny filosofie II. Prel. J. Cibulka, M. Sobotka, J. Tomin. Praha: Nakladatelství české akademie vied.

JOHNSON, M. - TARRANT, H. (eds.) (2012): Alcibiades and the Socratic Lover-Educator. London: Bristol Classical Press.

JOYAL, M. A. (1993): The Conclusion of Aeschines' Alcibiades. Rheinisches Museum für Philologie Neue Folge, Band 136, 263 - 268.

KAHN, C. H. (1994): Aeschines on Socratic Eros. In: Vander Waerdt, P. A. (ed.): The Socratic Movement. Ithaca: Cornell University Press, 87 - 106.

KALAŠ, A., SUVÁK, V. (2013): Antisthenove zlomky / Antisthenis fragmenta. Úvodná štúdia, preklad zlomkov a komentár. Fontes Socraticorum I. Bratislava: Vydavatel'stvo Univerzity Komenského.

LAMPE, K. (2015): Rethinking Aeschines of Sphettus. In: Zilioli, U. (ed.): From the Socratics to the Socratic Schools. New York - London: Routledge Press, $61-81$.

LAMPE, K. (2010): "Socratic Therapy" from Aeschines of Sphettus to Lacan. Classical Antiquity, 29 (2), $181-221$

LUISE, F. de - STAVRU, A. (eds.) (2013): Socratica III. Studies on Socrates, the Socratics, and Ancient the Socratic Literature. International Socrates Studies 1. Sankt Augustin: Academia Verlag.

MALLET, J.-A. (2013): The Notion of theia moira in Aeschines of Sphettus' Fragments. In: Luise, F. de - Stavru, A. (eds.): Socratica III. Studies on Socrates, the Socratics, and the Ancient Socratic Literature. Sankt-Augustin: Academia, 225 - 232.

MÁRSICO, C. (2017): Shock, Erotics, Plagiarism, and Fraud: Aspects of Aeschines' of Sphettus Philosophy. In: Stavru, A. - Moore, C. (eds.): Socrates and the Socratic Dialogue. Leiden: Brill, $202-220$. 
PASCALAU, G. (2013): Honig und Milch aus vertrockneten Brunnen: Eine dionysische Metapher bei Platon und Aischines von Sphettus. In: Luise, F. de - Stavru, A. (eds.): Socratica III. Studies on Socrates, the Socratics, and the Ancient Socratic Literature. Sankt-Augustin: Academia, 233 - 243.

PENTASSUGLIO, F. (2017): Eschine di Sfetto. Tutte le testimonianze. Turnhout: Brepols.

PENTASSUGLIO, F. (2017): Eschine di Sfetto: alcue nuove testimonianze. MÉTHEXIS, 29 (1), $59-88$.

PLÁCIDO, D. (2010): Esquines de Esfeto: las contradicciones del socratismo. In: Rossetti, L. Stavru, A. (eds.): Socratica 2008. Studies in Ancient Socratic Literature. Bari: Levante Editori, $119-133$.

PRINCE, S. H. (2015): Antisthenes of Athens: Texts, Translations, and Commentary. Michigan: University of Michigan Press.

REDFIELD, J. M. (2018): The Origins of the Socratic Dialogue: Plato, Xenophon, and the Others. In: Stavru, A. - Moore, C. (eds.): Socrates and the Socratic Dialogue. Leiden: Brill, 125 138.

ROSSETTI, L., LAUSDEI, C. (1979): Ancora sul "Milziade"di Eschine socratico: P. Oxy. 2890 (Back). Zeitschrift für Papyrologie und Epigraphik, Bd. 33 (1979), 47 - 56.

ROSSETTI, L. - STAVRU, A. (eds.) (2008): Socratica 2005. Studi sulla letteratura socratica antica presentati alle Giornate di studio di Senigallia. Bari: Levante Editori.

ROSSETTI, L. - STAVRU, A. (eds.) (2010): Socratica 2008. Studies in Ancient Socratic Literature. Bari: Levante Editori.

STAVRU, A. (2013): The Present State of Socratic Studies: An Overview. In: F. De Luise - A. Stavru (eds.): Socratica III: Studies on Socrates, the Socratics, and the ancient Socratic literature. Academia Verlag: Sankt Augustin, $11-26$.

STAVRU, A. - MOORE, C. (eds.) (2018): Socrates and the Socratic Dialogue. Leiden: Brill.

SUVÁK, V. (ed.) (2014a): Antisthenica Cynica Socratica. Praha: OIKOYMENH.

SUVÁK, V. (2014b): Sókratovská therapeia: Úloha Sókrata. Filozofia, 69, (10), 824 - 834.

SUVÁK, V. (2016a): Sókratovská terapia ako starost' o seba a druhých. In: Flachbartová, L., Sisáková O., Suvák, V.: Starost’o seba: Antické problematizácie života a súčasné myslenie. Prešov: Vydavatel'stvo Prešovskej univerzity, $9-61$.

SUVÁK, V. (2016b): Sókratovská therapeia: Platónov Charmidés 153a-158d. Filozofia, 71, (5), $357-368$.

SUVÁK, V. (2018a): On Dialectical Character of Antisthenes' Speeches Ajax and Odysseus. In: Stavru, A. - Moore, C. (eds.): Socrates and the Socratic Dialogue. Leiden: Brill, $141-160$.

SUVÁK, V. (2018b): Socratic Therapy as Taking Care of the Self and Others. In: Suvák, V. (ed.) Care of the Self: Ancient Problematizations of Life and Contemporary Thought. Leiden: Brill, $1-49$.

TARRANT, H. (2012): Improvement by Love: From Aeschines to the Old Academy. In: Johnson, M. - Tarrant, H. (eds.): Alcibiades and the Socratic Lover-Educator. London: Bristol Classical Press, $147-163$.

VANDER WAERDT, P. A. (ed.) (1994): The Socratic Movement. Ithaca and London: Cornell University Press.

VLASTOS, G. (1991): Socrates, Ironist and Moral Philosopher. Ithaca - New York: Cornell University Press.

ZELLER, E. (1922): Die Philosophie der Griechen. Teil II. 1 Abtheilung: Sokrates und die 
Sokratiker, 5. Auflage. Leipzig: Reisland.

ZILIOLI, U. (2012): The Cyrenaics. Bristol: Acumen Publishing.

ZILIOLI, U. (ed.) (2015): From the Socratics to the Socratic Schools: Classical Ethics, Metaphysics and Epistemology. New York - Oxon: Routledge.

Táto stat’ vznikla v rámci projektu VEGA č. 1/0017/17 Aischinés a sokratovský dialóg.

Lívia Flachbartová

Katedra bioetiky UNECSO

Filozofická fakulta PU v Prešove

17. novembra 1

08001 Prešov

Slovenská republika

e-mail: liv.flachbartova@gmail.com 